Journal of Physical Science, Vol. 28(1), 49-59, 2017

\title{
Health Risk Assessment of Heavy Metals in Soil, Irrigation Water and Vegetables Grown around Kubanni River, Nigeria
}

\author{
Nasir Sallau Lawal, " Owolona Agbo and Amina Usman \\ Department of Chemistry, Faculty of Science, \\ Ahmadu Bello University, 810282 Zaria, Nigeria \\ "Corresponding author: lawalnasir70@yahoo.com
}

Published online: 15 April 2017

To cite this article: Lawal, N. S., Agbo, O. \& Usman, A. (2017). Health risk assessment of heavy metals in soil, irrigation water and vegetables grown around Kubanni River, Nigeria. J. Phys. Sci., 28(1), 49-59, https://doi.org/10.21315/jps2017.28.1.4

To link to this article: https://doi.org/10.21315/jps2017.28.1.4

\begin{abstract}
The paper analyses the health risk assessment of cadmium (Cd), lead (Pb), zinc ( $\mathrm{Zn})$ and mercury $(\mathrm{Hg})$ in irrigation water, soil and two vegetables samples of three different farmlands grown along Kubanni River, Zaria, Nigeria. The concentrations of the heavy metals were determined using atomic absorption spectrophotometry (AAS). The analysis showed that the average concentration of $\mathrm{Pb}, \mathrm{Cd}, \mathrm{Zn}$ and $\mathrm{Hg}$ in the vegetable samples, irrigation water and soil of the three farmlands were 8.35, 1.76, 34.80 and $3.93 \mathrm{mg} \mathrm{kg}^{-1}$; 0.46, 0.09, 0.1 and $0.04 \mathrm{mg} \mathrm{kg}^{-1}$; and 7.22, 0.46, 16.46 and $2.03 \mathrm{mg} \mathrm{kg}^{-1}$ respectively. Generally, the transfer factors for the vegetables are in the order of $\mathrm{Cd}>\mathrm{Zn}$ $>\mathrm{Hg}>\mathrm{Pb}$. The associated health risk assessment of the heavy metals to consumers shows that $\mathrm{Pb}, \mathrm{Zn}$ and $\mathrm{Hg}$ in the vegetables were above the FAO/WHO permissible limits. The health risk values of daily intake of metal (DIM) and health risk index (HRI) indicates that $\mathrm{Pb}, \mathrm{Cd}$ and $\mathrm{Hg}$ contamination in the vegetables had the higher capability to pose severe health risk to consumers.
\end{abstract}

Keywords: Heavy metals, health risk, farmland, atomic absorption spectrophotometry, Kubanni River

\section{INTRODUCTION}

Environmental pollution is a major problem of growing medium sized settlements in developing countries, mainly due to uncontrolled pollution levels from industrial and municipal wastes that end up in rivers, lakes and sea. Plants take up heavy metals from the soil and in some cases by air deposition. However, contamination 
by heavy metals in some areas is practically inevitable due to natural process and anthropogenic activities (such as industrial, agricultural and domestic effluents). Recently, the food structure of the whole world greatly changed with increasing consumption of vegetables. However, vegetables can take up a lot of essential nutrients and certain trace elements in a short period. ${ }^{1,2}$ Therefore, the safety of vegetables is very important.

Kubanni River originates from Kampagi Hills and passes through several training institutions, several urban and rural settlements and flows into River Galma of Zaria, Nigeria. ${ }^{3}$ All kinds of domestic and industrial waste flow into the river untreated. Moreover, the river is used for irrigation and provides domestic water for Ahmadu Bello University (ABU) community from the Kubanni dam. As such, concerns have risen about heavy metal contamination in this area and the potential impact on food system and human health. ${ }^{4-6}$ Consequently, there is a need to carry out health risk assessment of these heavy metals on vegetables grown within the vicinity of river.

The present work is based on heavy metal concentrations of cadmium (Cd), zinc $(\mathrm{Zn})$, mercury $(\mathrm{Hg})$ and lead $(\mathrm{Pb})$ in vegetables grown around $\mathrm{ABU}$ Zaria dam area. In this study, onion (Allium cepa) and spinach (Spinacia oleracea) leaves and stem, the soil on which it was cultivated and the water for irrigation (i.e., the water from Kubanni River) were investigated.

\section{EXPERIMENTAL}

\subsection{General Description of Experimental Site}

The Kubanni River originates from Kampagi Hills and passes through several training institutions, several urban and rural settlements and flows into River Galma. In 1973, the Kubanni dam was constructed on River Kubanni Zaria, Nigeria. ${ }^{4}$ The lake is located approximately within latitude $11^{\circ} 11^{\prime} \mathrm{N}$ and longitude $7^{\circ} 38^{\prime} \mathrm{E}$ in Samaru Zaria, Kaduna State Nigeria. Its two major tributaries are the Kampangi and Samaru streams. The Samaru stream passes through the densely populated Samaru settlement and ABU main campus. It has an all year-round flow due to its sustenance by urban run offs and sewages.

The Samaru stream which is one of the tributaries of Kubanni River has a stream length of $1.05 \mathrm{~km}$ within an area of $2.28 \mathrm{~km}^{2}$ and a drainage density of $0.4605 \mathrm{~km} /$ $\mathrm{km}^{2} .^{7}$ The farmlands are located along Samaru stream which is one of the tributaries of Kubanni River close to ABU main campus. On a map, these farmlands (1, 2 and 
3) are located approximately within latitude $11^{\circ} 8^{\prime} 3^{\prime \prime} \mathrm{N}$, longitude $7^{\circ} 39^{\prime} 0^{\prime \prime} \mathrm{E}$ and sea level elevation of $645 \mathrm{~m}$ (Figure 1). All samples (soil, irrigation water, onion and spinach stem and leaves) were collected in June 2015. Three samples each of the soil and vegetables were collected from three different locations of three different farmlands and a litre of the irrigation water was used for the study.

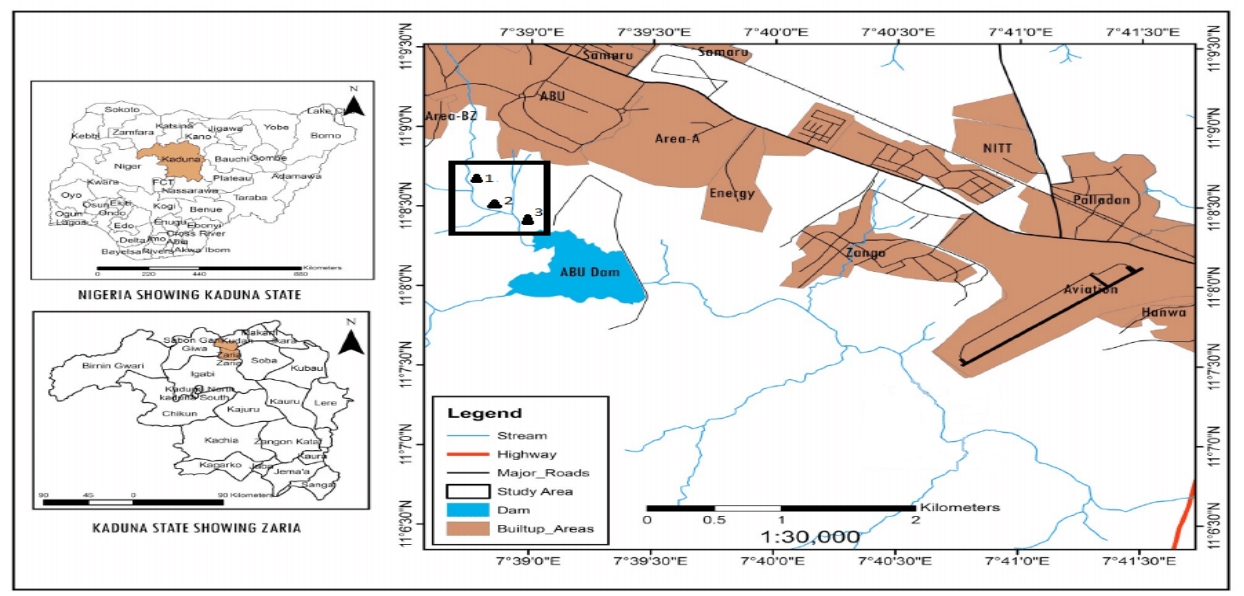

Figure 1: Map showing the sampling sites, adapted from QuickBird 2011 imaginary.

\subsection{Digestion of Soil Samples}

Soil samples were taken at least $1 \mathrm{~m}$ apart to a depth of $30 \mathrm{~cm}$ in the three different farmlands under investigation. The samples were digested by adopting the procedure of Chiroma T. M. et al. ${ }^{17}$

\subsection{Collection and Digestion of Vegetable Samples}

Vegetable samples were collected from three different farmlands around river Kubanni. The vegetables were washed with tap water and properly rinsed with distilled water and sliced into tiny pieces with a plastic knife. Digestion of the vegetable samples was achieved using the procedure of Chiroma T. M. et al. ${ }^{17}$

\subsection{Collection and Digestion of Water Samples}

A litre of the dam water used for irrigating the farm was collected and the procedure of Chiroma T. M. et al. was adopted for the digestion process. ${ }^{17}$ 


\subsection{Analysis of Samples}

Concentrations of $\mathrm{Pb}, \mathrm{Cd}, \mathrm{Zn}$ and $\mathrm{Hg}$ in the filtrate of digested soil, water and vegetables samples were estimated by using an Atomic Absorption Spectrophotometer (VARIAN 240FS, Sweden). Stock solutions, $1000 \mathrm{mg} \mathrm{l}^{-1}$ each of $\mathrm{Pb}, \mathrm{Cd}, \mathrm{Zn}$ and $\mathrm{Hg}$ purchased from Sigma-Aldrich were used for AAS analysis. Calibration standard for each element was prepared using these stock solutions by employing serial dilution technique. The mineral element composition in each sample was deduced from the calibration curves. For each sample, three determinations were performed and the average results were reported.

\subsection{Data Analysis}

\subsubsection{Transfer factor (TF)}

Metal concentrations in the extract of soils and vegetables were calculated by taking the ratio of the average metal concentration of the vegetable and the average metal concentration in the soil on the basis of dry weight $(\mathrm{mg} / \mathrm{kg}){ }^{8}$

\subsubsection{Daily intake of metal (DIM)}

For daily intake of metal (DIM), the average metal content in each vegetable was calculated and multiplied by the respective consumption rate. The DIM was determined by the following equation: ${ }^{9}$

$\mathrm{DIM}=\mathrm{C}_{\text {Metal conc. }} \times \mathrm{C}_{\text {Factor }} \times \mathrm{D}_{\text {Vegetable intake }}$

Here, $\mathrm{C}_{\text {Metal conc. }}=$ Heavy metal concentration in vegetables $\left(\mathrm{mg} \mathrm{kg}^{-1}\right) ; \mathrm{C}_{\text {Factor }}=$ conversion factor $(0.085)$; and $\mathrm{D}_{\text {Vegetable intake }}=$ Daily intake of vegetable $\left(\mathrm{kg}\right.$ person ${ }^{-1}$ day $\left.^{-1}\right)$.

The conversion factor of 0.085 is set to convert fresh vegetable weight to dry weight. ${ }^{10,11}$

\subsubsection{Health risk index (HRI)}

The hazardous quotient (HQ) for the consumption of contaminated vegetables was assessed by the ratio of DIM to the oral reference dose (RfD) for each metal. ${ }^{12}$ The consumption of the vegetable would be of no risk if the ratio is less than 1 and if the ratio is equal or greater than 1 then potential health risk is possible. ${ }^{12}$ 
Table 1: Oral reference doses (mg/kg/day) of metals under investigation.

\begin{tabular}{ll}
\hline Metal & Oral reference dose (RfD) \\
\hline $\mathrm{Pb}$ & $0.004^{\mathrm{a}}$ \\
$\mathrm{Cd}$ & $0.001^{\mathrm{a}}$ \\
$\mathrm{Zn}$ & $0.3^{\mathrm{a}}$ \\
$\mathrm{Hg}$ & $0.0003^{\mathrm{b}}$ \\
\hline
\end{tabular}

${ }^{a}$ FAO/WHO, 2013; ' ${ }^{b}$ US EPA 1987

\section{RESULTS AND DISCUSSION}

Table 2 summarises the mean heavy metals concentrations in the irrigation water, soil and vegetable samples grown around Kubanni River in three different farmlands. All analysed samples contained detectable concentrations of $\mathrm{Pb}, \mathrm{Cd}$, $\mathrm{Zn}$ and $\mathrm{Hg}$. Mean concentrations of the total $\mathrm{Pb}, \mathrm{Cd}, \mathrm{Zn}$ and $\mathrm{Hg}$ in the irrigation water samples were $0.46,0.09,0.1$ and $0.04 \mathrm{mg} \mathrm{kg}^{-1}$ respectively. The average concentrations of heavy metals in the soil samples of the three farmlands were in the order of $\mathrm{Zn}>\mathrm{Pb}>\mathrm{Hg}>\mathrm{Cd}$. Mean concentrations of $\mathrm{Pb}, \mathrm{Cd}, \mathrm{Zn}$ and $\mathrm{Hg}$ in the vegetable samples were $8.35,1.76,34.80$ and $3.93 \mathrm{mg} \mathrm{kg}^{-1}$ respectively.

The total concentration of $\mathrm{Pb}$ was higher in spinach stem and leaves than in onion samples in all the three farmlands. However $\mathrm{Cd}, \mathrm{Zn}$ and $\mathrm{Hg}$ concentrations were higher in onion than in spinach stem and leaves in all farmlands. Heavy metal concentrations varied among different vegetables which may be attributed to differential absorption capacity of test vegetables for different heavy metals. ${ }^{13}$

The maximum permissible limits for soil, water and vegetable samples are presented in Table 4. The average concentrations of $\mathrm{Pb}, \mathrm{Cd}, \mathrm{Zn}$ and $\mathrm{Hg}$ in all the vegetable samples were $8.35,1.76,34.80$ and $3.93 \mathrm{mg} \mathrm{kg}^{-1}$ respectively. These values have exceeded the maximum permissible limits set by FAO/WHO (2007) and USEPA (2010) except Zn which was within tolerable limit. Similarly, the concentration of heavy metals in the soil and water samples for $\mathrm{Pb}, \mathrm{Cd}$ and $\mathrm{Hg}$ were above the FAO/WHO (2007) and USEPA (2010) maximum permissible limits except Zn was below the permissible limit. It seems the irrigation water and soil of the study area naturally have high concentrations of $\mathrm{Pb}, \mathrm{Cd}$ and $\mathrm{Hg}$ which may come from atmospheric deposition by air, sewage water or other anthropogenic sources. 
Table 2: Mean heavy metals concentrations $\left(\mathrm{mg} \mathrm{kg}^{-1}\right)$ in the irrigation water, soil and vegetable samples grown around Kubanni River in three different farmlands.

\begin{tabular}{clcccc}
\hline \multirow{2}{*}{ Farmland } & Sample & \multicolumn{4}{c}{ Mean heavy metal concentration $\left(\mathrm{mg} \mathrm{kg}^{-1}\right)$} \\
\cline { 3 - 6 } & & $\mathrm{Pb}$ & $\mathrm{Cd}$ & $\mathrm{Zn}$ & $\mathrm{Hg}$ \\
\hline \multirow{3}{*}{1} & Water & 0.46 & 0.09 & 0.10 & 0.04 \\
& Soil & 8.70 & 0.37 & 23.68 & 2.11 \\
& Onion & 2.60 & 5.80 & 65.47 & 6.35 \\
& Spinach leaves & 10.42 & 0.21 & 22.68 & 1.06 \\
& Spinach stem & 17.18 & 0.31 & 10.98 & 1.37 \\
\hline \multirow{3}{*}{2} & Water & 0.46 & 0.09 & 0.10 & 0.04 \\
& Soil & 4.39 & 0.50 & 11.89 & 2.12 \\
& Onion & 6.40 & 6.00 & 74.93 & 9.54 \\
& Spinach leaves & 7.19 & 0.22 & 12.92 & 1.54 \\
& Spinach stem & 13.67 & 0.42 & 10.80 & 1.73 \\
\hline \multirow{3}{*}{3} & Water & 0.46 & 0.09 & 0.10 & 0.04 \\
& Soil & 8.58 & 0.51 & 13.82 & 1.85 \\
& Onion & 1.20 & 2.47 & 93.80 & 10.83 \\
& Spinach leaves & 8.35 & 0.11 & 11.89 & 1.40 \\
& Spinach stem & 8.18 & 0.26 & 9.72 & 1.54 \\
\hline
\end{tabular}

Table 3: Transfer factor of the vegetable samples grown around Kubanni River in three different farmlands.

\begin{tabular}{clcccc}
\hline \multirow{2}{*}{ Farmland } & Sample & \multicolumn{4}{c}{ Transfer factor } \\
\cline { 3 - 6 } & & $\mathrm{Pb}$ & $\mathrm{Cd}$ & $\mathrm{Zn}$ & $\mathrm{Hg}$ \\
\hline \multirow{3}{*}{1} & Onion & 0.30 & 15.68 & 2.76 & 3.01 \\
& Spinach leaves & 1.20 & 0.57 & 0.96 & 0.50 \\
& Spinach stem & 1.97 & 0.84 & 0.46 & 0.65 \\
\hline \multirow{2}{*}{2} & Onion & 1.46 & 11.90 & 6.30 & 4.50 \\
& Spinach leaves & 1.64 & 0.44 & 1.09 & 0.73 \\
& Spinach stem & 3.12 & 0.83 & 0.91 & 0.82 \\
\hline \multirow{2}{*}{3} & Spinach leaves & 0.14 & 4.88 & 6.79 & 5.84 \\
& Spinach stem & 0.97 & 0.22 & 0.86 & 0.75 \\
\hline
\end{tabular}

The mean metal transfer factors for the vegetables are presented in Table 3. Generally, the transfer factors for the vegetables are in the order $\mathrm{Cd}>\mathrm{Zn}>\mathrm{Hg}>$ $\mathrm{Pb}$. There is a high transfer factor of $\mathrm{Cd}, \mathrm{Zn}$ and $\mathrm{Hg}$ in onion samples than spinach 
stem and leaves, this could be attributed to the initial high mean concentration of the elements, as determined in Table 2.

Table 4: Guideline of safe limits for heavy metals.

\begin{tabular}{llllll}
\hline Sample & Standard & $\mathrm{Pb}$ & $\mathrm{Zn}$ & $\mathrm{Cd}$ & $\mathrm{Hg}$ \\
\hline $\begin{array}{l}\text { Water } \\
\left(\mathrm{mg} \mathrm{l}^{-1}\right)\end{array}$ & FAO/WHO 2007 & 5.0 & 2.0 & 0.01 & $0.001^{\mathrm{a}}$ \\
$\begin{array}{l}\text { Soil } \\
\left(\mathrm{mg} \mathrm{kg}^{-1}\right)\end{array}$ & USEPA 2010 & 300 & 200 & 3.0 & 0.3 \\
$\begin{array}{l}\text { Plant } \\
\left(\mathrm{mg} \mathrm{kg}^{-1}\right)\end{array}$ & FAO/WHO 2007 & 5.0 & 60.0 & 0.2 & 0.0016 \\
\hline
\end{tabular}

${ }^{a}$ WHO, 2004

Table 5: Estimation of daily intake of metals ( $\mathrm{mg} / \mathrm{person} /$ day) by consumption of the vegetable samples grown around Kubanni River in three different farmlands.

\begin{tabular}{|c|c|c|c|c|c|}
\hline \multirow{2}{*}{ Farmland } & & \multicolumn{4}{|c|}{ Estimation of daily intake of metals } \\
\hline & & $\mathrm{Pb}$ & $\mathrm{Cd}$ & $\mathrm{Zn}$ & $\mathrm{Hg}$ \\
\hline \multirow{6}{*}{1} & \multirow{2}{*}{ Onion } & 0.0014 (A) & $0.0030(\mathrm{~A})$ & 0.0343 (A) & $0.0033(\mathrm{~A})$ \\
\hline & & $0.0016(\mathrm{C})$ & $0.0035(\mathrm{C})$ & $0.0395(\mathrm{C})$ & $0.0038(\mathrm{C})$ \\
\hline & \multirow{2}{*}{$\begin{array}{l}\text { Spinach } \\
\text { leaves }\end{array}$} & 0.0055 (A) & $0.0001(\mathrm{~A})$ & 0.0119 (A) & $0.0006(\mathrm{~A})$ \\
\hline & & $0.0063(\mathrm{C})$ & $0.0001(\mathrm{C})$ & $0.0137(\mathrm{C})$ & $0.0006(\mathrm{C})$ \\
\hline & \multirow{2}{*}{$\begin{array}{l}\text { Spinach } \\
\text { stem }\end{array}$} & $0.0090(\mathrm{~A})$ & $0.0002(\mathrm{~A})$ & $0.0058(\mathrm{~A})$ & 0.0007 (A) \\
\hline & & $0.0104(\mathrm{C})$ & $0.0002(\mathrm{C})$ & $0.0066(\mathrm{C})$ & $0.0008(\mathrm{C})$ \\
\hline \multirow{6}{*}{2} & \multirow{2}{*}{ Onion } & 0.0034 (A) & $0.0031(\mathrm{~A})$ & 0.0393 (A) & 0.0050 (A) \\
\hline & & $0.0039(\mathrm{C})$ & $0.0036(\mathrm{C})$ & $0.0452(\mathrm{C})$ & $0.0058(\mathrm{C})$ \\
\hline & \multirow{2}{*}{$\begin{array}{l}\text { Spinach } \\
\text { leaves }\end{array}$} & $0.0038(\mathrm{~A})$ & $0.0001(\mathrm{~A})$ & $0.0068(\mathrm{~A})$ & $0.0008(\mathrm{~A})$ \\
\hline & & $0.0043(\mathrm{C})$ & $0.0001(\mathrm{C})$ & $0.0078(\mathrm{C})$ & $0.0009(\mathrm{C})$ \\
\hline & \multirow{2}{*}{$\begin{array}{l}\text { Spinach } \\
\text { stem }\end{array}$} & $0.0072(\mathrm{~A})$ & $0.0002(\mathrm{~A})$ & 0.0057 (A) & $0.0009(\mathrm{~A})$ \\
\hline & & $0.0082(\mathrm{C})$ & $0.0003(\mathrm{C})$ & $0.0065(\mathrm{C})$ & $0.0010(\mathrm{C})$ \\
\hline \multirow{6}{*}{3} & \multirow{2}{*}{ Onion } & $0.0006(\mathrm{~A})$ & 0.0013 (A) & $0.0492(\mathrm{~A})$ & 0.0057 (A) \\
\hline & & $0.0007(\mathrm{C})$ & $0.0015(\mathrm{C})$ & $0.0566(\mathrm{C})$ & $0.0065(\mathrm{C})$ \\
\hline & \multirow{2}{*}{$\begin{array}{l}\text { Spinach } \\
\text { leaves }\end{array}$} & 0.0044 (A) & $0.0001(\mathrm{~A})$ & $0.0062(\mathrm{~A})$ & $0.0007(\mathrm{~A})$ \\
\hline & & $0.0050(\mathrm{C})$ & $0.0001(\mathrm{C})$ & $0.0072(\mathrm{C})$ & $0.0008(\mathrm{C})$ \\
\hline & \multirow{2}{*}{$\begin{array}{l}\text { Spinach } \\
\text { stem }\end{array}$} & 0.0043 (A) & $0.0001(\mathrm{~A})$ & $0.0051(\mathrm{~A})$ & 0.0008 (A) \\
\hline & & 0.0049 (C) & $0.0002(\mathrm{C})$ & 0.0059 (C) & $0.0009(\mathrm{C})$ \\
\hline
\end{tabular}

$A=$ Adults, $C=$ Children

DIMs were calculated for adult and children are presented in Table 5. In general, the DIM values of $\mathrm{Cd}, \mathrm{Zn}$ and $\mathrm{Hg}$ in onion are higher than in spinach stem and 
leaves. Whereas, DIM values of $\mathrm{Pb}$ were prominent in spinach leaves and stems. Overall, the average DIM values were in the order of $\mathrm{Zn}>\mathrm{Pb}>\mathrm{Hg}>\mathrm{Cd}$. From the results $\mathrm{DIM}$ value of $\mathrm{Pb}$ and $\mathrm{Hg}$ in spinach exceeded the FAO/WHO (2013) and USEPA (1987) limit of 0.004 and 0.0003 respectively for daily consumption of the two metals. Therefore, daily consumption of contaminated plants may cause severe health risks by ingestion of $\mathrm{Pb}$ and $\mathrm{Hg}$ through spinach stems and leaves cultivated in the study area while the estimated DIM of Cd and $\mathrm{Zn}$ are in the range of safe limits set by FAO/WHO (2013). ${ }^{14}$ However, the DIM value of $\mathrm{Pb}, \mathrm{Cd}$ and $\mathrm{Zn}$ in onion samples are in the range of safe limits set by FAO/WHO (2013) for daily consumption except the estimated DIM value of $\mathrm{Hg}$ which has exceeded the limits set by USEPA (1987). ${ }^{15}$ It is clear that $\mathrm{Hg}$ might be ingested through onion samples which may cause severe health risk especially for pregnant mothers and children. ${ }^{16}$

Table 6: Health risk index (HRI) of the metals for the adults and children as a result of consumption of the vegetables.

\begin{tabular}{|c|c|c|c|c|c|}
\hline \multirow{2}{*}{ Farmland } & \multirow{2}{*}{ Sample } & \multicolumn{4}{|c|}{ Health risk index } \\
\hline & & $\mathrm{Pb}$ & $\mathrm{Cd}$ & $\mathrm{Zn}$ & $\mathrm{Hg}$ \\
\hline \multirow{6}{*}{1} & Onion & $0.341(\mathrm{~A})$ & $3.043(\mathrm{~A})$ & $0.114(\mathrm{~A})$ & $11.096(\mathrm{~A})$ \\
\hline & & $0.392(\mathrm{C})$ & $3.498(\mathrm{C})$ & $0.132(\mathrm{C})$ & $12.755(\mathrm{C})$ \\
\hline & Spinach leaves & 1.367 (A) & 0.110 (A) & 0.040 (A) & $1.847(\mathrm{~A})$ \\
\hline & & $1.571(\mathrm{C})$ & $0.127(\mathrm{C})$ & $0.046(\mathrm{C})$ & $2.123(\mathrm{C})$ \\
\hline & Spinach stem & $2.253(\mathrm{~A})$ & $0.163(\mathrm{~A})$ & 0.019 (A) & 2.387 (A) \\
\hline & & $2.590(\mathrm{C})$ & $0.187(\mathrm{C})$ & $0.022(\mathrm{C})$ & $2.744(\mathrm{C})$ \\
\hline \multirow{6}{*}{2} & Onion & 0.839 (A) & $3.148(\mathrm{~A})$ & $0.131(\mathrm{~A})$ & $16.677(\mathrm{~A})$ \\
\hline & & $0.965(\mathrm{C})$ & $3.618(\mathrm{C})$ & $0.151(\mathrm{C})$ & $19.172(\mathrm{C})$ \\
\hline & Spinach leaves & $0.943(\mathrm{~A})$ & $0.115(\mathrm{~A})$ & $0.023(\mathrm{~A})$ & $2.689(\mathrm{~A})$ \\
\hline & & $1.084(\mathrm{C})$ & $0.133(\mathrm{C})$ & $0.026(\mathrm{C})$ & $3.092(\mathrm{C})$ \\
\hline & Spinach stem & $1.793(\mathrm{~A})$ & $0.220(\mathrm{~A})$ & $0.019(\mathrm{~A})$ & 3.029 (A) \\
\hline & & $2.061(\mathrm{C})$ & $0.253(\mathrm{C})$ & $0.022(\mathrm{C})$ & $3.482(\mathrm{C})$ \\
\hline \multirow{6}{*}{3} & Onion & $0.157(\mathrm{~A})$ & $1.296(\mathrm{~A})$ & $0.164(\mathrm{~A})$ & $18.934(\mathrm{~A})$ \\
\hline & & $0.181(\mathrm{C})$ & $1.490(\mathrm{C})$ & $0.189(\mathrm{C})$ & $21.766(\mathrm{C})$ \\
\hline & Spinach leaves & $1.095(\mathrm{~A})$ & $0.058(\mathrm{~A})$ & $0.021(\mathrm{~A})$ & $2.441(\mathrm{~A})$ \\
\hline & & $1.259(\mathrm{C})$ & $0.066(\mathrm{C})$ & $0.024(\mathrm{C})$ & $2.806(\mathrm{C})$ \\
\hline & Spinach stem & $1.073(\mathrm{~A})$ & $0.136(\mathrm{~A})$ & $0.017(\mathrm{~A})$ & $2.684(\mathrm{~A})$ \\
\hline & & $1.233(\mathrm{C})$ & $0.157(\mathrm{C})$ & $0.020(\mathrm{C})$ & $3.086(\mathrm{C})$ \\
\hline
\end{tabular}

$A=$ Adults, $C=$ Children 
On the other hand, Table 6 presented the health risk index (HRI) of the metals for the adults and children as a result of consumption of the vegetables. The HRIs of $\mathrm{Pb}, \mathrm{Cd}, \mathrm{Zn}$ and $\mathrm{Hg}$ ranged about $0.16-2.25,0.11-3.15,0.017-0.16$ and $1.85-18.93$, respectively for adults, and $0.18-2.59,0.13-3.49,0.020-0.189$ and $2.12-21.77$ for children, respectively. The highest HRI value of 21.77 was observed for children through $\mathrm{Hg}$ consumption in onion sample of farmland 3 while the lowest $(0.017)$ was observed for adults through $\mathrm{Zn}$ consumption in spinach stem of farmland 3 . The result showed that $\mathrm{Pb}, \mathrm{Cd}$ and $\mathrm{Hg}$ contamination in the vegetables had the higher capability to pose severe health risk to consumers since most of the HRIs of the vegetables in all the farmlands were greater than 1 .

\section{CONCLUSION}

The present study has assessed data on heavy metals in irrigation water, soil and two kinds of vegetables (edible parts) grown around Kubanni River, Zaria, Nigeria. All the samples under investigation contained detectable concentrations of $\mathrm{Pb}, \mathrm{Cd}, \mathrm{Zn}$ and $\mathrm{Hg}$. The associated health risk assessment of the heavy metals to consumers shows that $\mathrm{Pb}, \mathrm{Zn}$ and $\mathrm{Hg}$ in the vegetables were above the FAO/WHO (2007) permissible limits. These accumulated heavy metals have affected the soil and are easily transferred to the vegetables grown around the area. The findings of this study regarding DIM and HRI indicates that $\mathrm{Pb}, \mathrm{Cd}$ and $\mathrm{Hg}$ contamination in the vegetables had the higher capability to pose severe health risk to consumers. Therefore, there is the need for the authorities concern to come up with measures that would stop the indiscriminate dumping of refuse and discharge of untreated sewage into the Kubanni River.

\section{ACKNOWLEDGEMENTS}

The authors thankfully acknowledge the support provided by the Multi-User Science Research Laboratory, Ahmadu Bello University, Zaria, Nigeria.

\section{REFERENCES}

1. Zhou, D. M. et al. (2005). Copper and zinc uptake by radish and pakchoi as affected by application of livestock and poultry manures. Chemosph., 59, 167-175, https://doi.org/10.1016/j.chemosphere.2004.11.008. 
2. Liu, H. Y. et al. (2005). Metal contamination of soils and crops affected by the Chenzhou lead/zinc mine spill (Hunan, China). Sci. Total Environ., 339, 153-166, https://doi.org/10.1016/j.scitotenv.2004.07.030.

3. Butu, A. W. \& Iguisi, E. O. (2013). Concentration of heavy metals in sediment of river Kubanni, Zaria, Nigeria. Compr. J. Earth Environ. Sci., 2(1), 10-17.

4. Haruna, A. (2008). Trace metal risk assessment in vegetable crops irrigated with sewage water and sludge along Kubanni river drainage basin in Zaria metropolis, Nigeria. Masters diss., Ahmadu Bello University, Zaria, Nigeria.

5. Butu, A. W. \& Iguisi, E. O. (2012). Increasing levels of metal pollutants in river Kubanni Zaria, Nigeria. Res. J. Environ. Earth Sci., 4(12), 1085-1089.

6. Oladeji, S. O.\& Saeed, M. D. (2015). Assessment of cadmium concentrations in wastewater, soil and vegetable samples grown along Kubanni stream channels in Zaria, Kaduna State, Nigeria J. Chem. Pharm. Res., 7(9), 332339.

7. Butu, A. W. \& Ati, O. F. (2013). Sources and levels of concentration of metal pollutants in Kubanni dam, Zaria, Nigeria. Int. J. Dev. Sustain., 2(2), 814824.

8. Cui, Y. J. et al. (2004). Transfer of metals from near a smelter in Nanning. China. Environ. Int., 30, 785-791, https://doi.org/10.1016/j. envint.2004.01.003.

9. Sajjad, K. et al. (2009). Health risk assessment of heavy metals for population via consumption of vegetables. World Appl. Sci. J., 6(12), 1602-1606.

10. USDA. (2007). USDA nutrient database for standard reference, release 2007. Retrieved 20 February 2016 from http://www.ars.usda.gov/main/site_main. htm? modecode $=12-35-45-00$.

11. Rattan, R. K. et al. (2005). Long-term impact of irrigation with sewage effluents on heavy metal content in soils, crops and groundwater - A case study. Agri. Ecosyst. Environ., 109, 310-322, https://doi.org/10.1016/j. agee.2005.02.025.

12. USEPA. (2013). Reference dose (RfD): Description and use in health risk assessments. Background document 1A, Integrated Risk Information System (IRIS), United States Environmental Protection Agency. Retrieved 15 March 2016 from http://www.epa.gov/iris/rfd.htm.

13. Zurera-Cosano, G. et al. (1989). Heavy metal uptake from greenhouse border soils for edible vegetables. J. Sci. Food Agri., 49, 307-314, https:// doi.org/10.1002/jsfa.2740490307.

14. FAO/WHO. (2013). Guidelines for the safe use of wastewater and food stuff. Wastewater use in Agriculture. Report by WHO, Geneva.

15. USEPA. (1987). Peer workshop on mercury issues. Summary report, 26-27 October, Environmental Criteria and Assessment Office, USEPA. 
16. Bose-O'Reilly, S. et al. (2010). Mercury exposure and children's health. Curr. Probl. Ped. Adoles. Health Care, 40(8), 186-215, https://doi.org/10.1016/j. cppeds.2010.07.002.

17. Chiroma T. M., Ebewele R. O. \& Hymore F. K. (2012). Levels of heavy metals $(\mathrm{Cu}, \mathrm{Zn}, \mathrm{Pb}, \mathrm{Fe}$ and $\mathrm{Cr}$ ) in bushgreen and roselle irrigated with treated and untreated urban sewage water. Int. Res. J. Environment Sci., 1(4), 1-7. 